\title{
RANKING SERVICE QUALITY USING MULTI-CRITERIA DECISION-MAKING METHODS: EXAMPLE OF ERZURUM PROVINCE
}

\author{
Çağlar KARAMAŞA ${ }^{1 *}$ \\ ${ }^{1}$ Anadolu University, Faculty of Business, Department of Business Administration, Yunusemre Campus, \\ 26470, Tepebaşı/Eskişehir, Turkey, ckaramasa@anadolu.edu.tr
}

\begin{abstract}
In the tourism sector, where competition conditions are getting stiffer, some of the essential factors to hotels stay operational include the need to achieve a sustainable structure and meet the needs and expectations of customers. One of the ways to ensure that the customer expectations and needs are met at the desired level is through service quality factors which are considered to increase customer satisfaction. This study aims to establish the service quality criteria in three-star hotels in Erzurum and to rank the importance levels of the determined criteria. The SWARA method was used to weight the determined criteria. The results of the SWARA method show that the "Price Availability" was the most important service quality criteria in three-star hotels. This was followed by "Courtesy and Respect Level", "Reliability", "Service and Process Flexibility", "Restaurant Service Quality" and "Cleanliness" respectively. The criteria considered as the least important include "Quality of Housekeeping" and "Front Office Service Quality".
\end{abstract}

Keywords: Tourism, Hotels, Service Quality, SWARA Method

Original scientific paper

Received: 08.08.2021

Accepted: 23.08.2021

Available online: 07.09.2021

\section{Introduction}

In today's information age, price has ceased to be the sole competitive factor and has lost its significance to a large extent. Quality has come to the fore as the determining factor of the competitive environment. In this way, factors like first-time quality, service quality, customer satisfaction, and organizational performance, which are the basic determinants of price and quality policies have emerged and spread rapidly (Korucuk et al., 2015).

These concepts hold as much significance in the service sector just as much as they do in the production industry and are indeed a critical component required by all businesses that seek sustainability and continued existence. In the tourism sector, one of the foremost service sectors, factors like quality, especially service quality, can thus be considered as vital strategic functions.

\footnotetext{
* Corresponding author
} 
Han and Baek (2004) defined the concept of service quality as the general impression left on both the internal and external customers by the services used and rendered by a business while in pursuit of the competitive edge.

Parasuraman et al. (1985) defined it as the difference between expected and perceived service and outlined the dimensions of service quality as physical characteristics, reliability, responsiveness, trust, and empathy.

In another definition, service quality is termed as the extent to which the demands and needs of consumers and the expected features of the service are met, and the degree to which the service has the necessary qualifications (Odabaşı, 2000).

Gilmore (2003) outlined the dimensions of service quality as tangible features as well as non-tangible including image, reliability, responsiveness, competence, accessibility, courtesy, communication, reputation, security, and empathy.

Kurtz and Clow (1998), however, stated that service quality standards are elements that can only be determined by customer perceptions and through their feedback to the business. It should be noted that the services offered are a structure that will be shaped by the perceptions of customers of service quality standards. Businesses need to determine the service quality based on their own standards and then redesign it according to the reactions of the customers. They stated that the insistence of business management on their own understanding of quality standards will lead to negative results.

Erdal and Korucuk (2016) on the other hand, state that the quality of outputs mostly depends on the support of suppliers (and the other units providing support). When supplier departments are not managed as part of a compatible system, they may ignore the needs of their customers. These customers, in turn, may ignore the needs of their own customers. This chain of neglect in all units eventually leads to compromised service quality.

The quality of service in the tourism sector, however, is defined by a variety of determinants which include the expectations of the tourists regarding the goods and the services they are presented with as well as other factors like security and hygiene. These factors make the service quality elements of tourism enterprises differ from other sectors (Attallah, 2015).

Akyurt (2021) stated that hotels should keep their service quality standards high for sustainable tourism development and demand. The tourism sector has an ever-increasing number of similar hotels and thus the state of service quality provides a significant advantage in the competition. The opportunities created by the advances in transport and communication have expanded the competition in the sector beyond the borders of any nation. There is, therefore, a need for players in the sector to distinguish themselves from the others through the quality of their services if they are to remain sustainable.

Korucuk et al. (2019) stated that the multidimensional structure of service quality due to its tangible and intangible elements makes it difficult to ensure its standardization. He argued that since the increase in quality standards also directly affects the operating costs, enterprises in the sector that deal both in products and services should examine it more intently, determining the factors that affect the service quality and evaluating these factors as they affect the tourism sector.

Kotler et al. (2003) stated that as much as providing service quality may prove difficult for businesses in the tourism sector, the enterprises that attain the ideal service quality have an ensured continuity of touristic demand. They also observed that the benefits of service quality 
to businesses consist of four items; it ensures customer loyalty, contributes to competitive advantage, lays the groundwork for qualified personnel, and helps to reduce costs.

The dimensions of service quality in tourism and other sectors have been considered in many studies that have used different methods to measure this phenomenon. The measurement models for service quality in tourism and the other sectors can generally be classified as follows. Technical and functional quality model, difference model, dimension/feature service quality model, SERVPERF Performance-based model, service quality ideal value model, performance evaluation and standard quality model, information technology fit model, characteristic and overall impact model, perceived service quality, and satisfaction model, service quality, consumer value, and consumer satisfaction model, previous effects and intermediary factors model and internal service quality model. (Temizel \& Garda, 2017).

The tourism sector, seen as one of the most important in the service sector, has seen an increase in the number of academic and sectoral studies on service quality. These studies have found that hotels have prioritized the issue of customer satisfaction, especially from the 1980s onwards. The scientific studies on service quality in an academic sense have generally focused on the service quality criteria that are considered to affect hotels. A fast race has been entered in terms of service quality both in the academic sense and in the tourism sector. Due to the similarity of the services offered by the hotels, the service quality level that addresses the preferences of the tourists has become the main factor (Tsaur \& Lin, 2004).

Every business, especially in today's environment, wants to improve its competitiveness and increase business efficiency. Most businesses often adopt a flexible structure to achieve this. A function of this flexibility and competitiveness is service quality for businesses. Service quality has become widely accepted as one of the key indicators that play an important role in customer satisfaction and business success (Korucuk, 2018).

The study aims to rank hotel enterprises based on their service quality criteria due to the emphasized significance of these criteria. This study sought to rank the significance levels of the criteria affecting the service quality in three-star hotel businesses in Erzurum. The SWARA method, one of the multi-criteria decision-making methods, was used.

The rest of the study proceeds as follows. The literature review on service quality has been considered in the following section, followed by the theoretical explanations of the SWARA method, which is the method used in the study. The next section outlines the application of the method in Erzurum followed by the findings and the results. The last section gives the conclusion of the study which provides recommendations regarding the limitations of the study and the work that can be done in the future.

\section{Literature Review}

This section highlights some of the studies that measured service quality in the hotel business.

In a study conducted across 14 different sectors, Anderson et al. (1994) examined the positive effects of service quality on consumer satisfaction and profitability.

Kahraman (1996) gave various examples explaining how enterprises in the tourism sector can develop and maintain their existence under tough competition conditions by relying on high and continuity of service quality. 
Tsang and Qu (2000) surveyed 90 hotel managers and 270 tourists staying in hotels in three modern cities of China to measure service quality. They evaluated the expectations of tourists and hotel managers against the service quality they experienced when they came to the hotel.

Tian-Cole and Cromption (2003) stated in their study that training that incorporates the management and staff, emphasizing the importance of quality, and providing training on quality is likely to increase the quality of service.

Nadiri and Hussain (2005) conducted a survey among 400 international guests from countries including England, Scotland, and Germany staying in four-star, five-star, and resort hotels in North Cyprus and developed the Service Performance Model (SERVPERF) to determine the service quality received by the customers.

Murat and Çelik (2007) examined the service quality of three-star hotels licensed to render tourism services in the province of Bartın and determined the best hotel alternative by comparatively evaluating them using the Analytical Hierarchy Process (AHS).

Hsieh et al. (2008) measured service quality using the five dimensions of the SERVQUAL scale with a questionnaire they adapted in four spa hotels in Taiwan.

K1lıç and Eleren (2010) measured service quality on three five-star hotels operating in Afyonkarahisar, which is considered the capital of thermal tourism, using the SERVQUAL scale. They determined that the difference between expected and perceived quality in one of the three hotels was less than in other businesses.

Kenzhebayeva (2012) stated in their study on service quality in the tourism sector that income level impacts the perception of service quality.

Çabuk et al. (2013) investigated the relationship between image of the hotel in the customers' eyes and service quality perceptions and their repeat purchasing behavior in a study conducted on 380 hotel customers staying in two, three, four, and five-star hotels in Adana.

Günaydın (2015) analyzed the quality and loyalty of the service provided in a five-star accommodation business operating in Bodrum from the perspectives of the customers.

Jasinskas et al. (2016) conducted a study that considered 205 tourists staying in four-star hotels in the Lithuanian Kaunas region. They found that the small difference between the expected quality and perceived quality of the tourists has a significant effect on brand loyalty levels.

Ashraf et al. (2018) investigated the effect of perceived service quality and perceived value on brand loyalty in their study with 440 customers in the hospital, hotel, education, and banking service sectors.

Korucuk et al. (2019) considered expert opinions and the entropy method to determine the most important criteria that constitute the service standards for a hotel business.

Roy et al. (2019) examined the development of a Web-based hotel evaluation and selection system using the COPRAS method.

Demirağ and Durmaz (2019) measured the effect of perceived service quality on perceived value and attitudinal brand loyalty on 450 hotel customers staying in five-star resorts and city hotels in Ankara and Antalya.

Kılıç et al. (2020) used AHP - TOPSIS methods to carry out the prioritization of service quality dimensions in thermal tourism and then do a ranking of hotels. 
Onurlubaş and Öztürk (2020) examined the effect of service quality on customer satisfaction in boutique hotels in Antalya.

Nguyen (2021) used fuzzy AHP-based SERVQUAL to measure hotel service quality.

Akyurt (2021); used the entropy method, which is one of the multi-criteria decision-making methods, in combination with face-to-face interviews with managers drawn from four- and five-star hotels in Ordu province to examine the service quality criteria.

Although there are several studies on the ranking of service quality criteria in hotel businesses in the literature considered, the method employed in this study as well as the location chosen gives this study its unique value and a different perspective of contribution to the general literature.

Studies related to SWARA methodology can be seen as Table 1.

Table 1. Studies related to SWARA method

\begin{tabular}{|c|c|c|}
\hline Author(s) & Benchmark & Application \\
\hline Veskovic et al. (2018) & DELPHI-SWARA-MABAC & $\begin{array}{l}\text { Evaluating railway } \\
\text { management models in } \\
\text { Bosnia and Herzegovina }\end{array}$ \\
\hline Alimardani et al. (2013) & SWARA-VIKOR & $\begin{array}{l}\text { Supplier selection in agile } \\
\text { environment }\end{array}$ \\
\hline Aghdaie et al. (2013) & SWARA-COPRAS-G & $\begin{array}{l}\text { Machine tool selection in } \\
\text { manufacturing company in } \\
\text { Iran }\end{array}$ \\
\hline Zolfani \& Bahrami (2014) & SWARA-COPRAS & $\begin{array}{l}\text { Decision and policy making } \\
\text { in priority of high tech } \\
\text { industries in Iran. }\end{array}$ \\
\hline Rani et al. (2020) & $\begin{array}{l}\text { Hesitant fuzzy SWARA- } \\
\text { COPRAS }\end{array}$ & $\begin{array}{l}\text { Evaluate and select the } \\
\text { desirable sustainable supplier }\end{array}$ \\
\hline Ghenai et al. (2020) & Hybrid SWARA-ARAS & $\begin{array}{l}\text { Assessing sustainability } \\
\text { indicators for renewable } \\
\text { energy systems }\end{array}$ \\
\hline Prajapati et al. (2019) & SWARA-WASPAS & $\begin{array}{l}\text { Identify and prioritize the } \\
\text { solutions for mitigating the } \\
\text { impact of barriers to reverse } \\
\text { logistics implementation }\end{array}$ \\
\hline Dahooie et al. (2018) & SWARA-ARAS-G & $\begin{array}{l}\text { Competency based IT } \\
\text { personnel selection }\end{array}$ \\
\hline Urosevic et al. (2017) & SWARA-WASPAS & $\begin{array}{l}\text { Selection of personnel for the } \\
\text { position of sales manager in } \\
\text { the tourism sector }\end{array}$ \\
\hline Ulutaş et al. (2020) & Fuzzy SWARA-CoCoSo & $\begin{array}{l}\text { Location selection for logistics } \\
\text { center }\end{array}$ \\
\hline
\end{tabular}

\section{Methodology}

This study used SWARA, a Multi-Criteria Decision Making (MCDM) method, to determine the service quality criteria in three-star hotels in Erzurum and to rank the importance levels of the determined criteria. The choice of an MCDM method is based on their ability to be applied 
differently from statistical analysis techniques, as they can evaluate both objective and nonobjective factors together. Analyzes used in these methods follow expert opinions and can be tailored to give results based on the opinion of just a single expert or the opinions of a group of experts (Korucuk, 2019).

In this section, the SWARA method, which is used to rank the importance levels of service quality criteria in hotel businesses, is explained.

\subsection{SWARA Method}

SWARA, considering uncertainties happened in evaluating criteria and alternatives by linguistic expressions, is one of the mostly used MCDM methods recently (Korucuk,2019). The main advantage of this method in decision making process is to define based on policies of companies or countries without needing for evaluation to rank criteria (Kouchaksaraei et al., 2015). In this context, steps of SWARA method can be summarized as below (Ruzgys et al. 2014; Stanujkic et al. 2015):

a) Ranking criteria: Criteria are sorted in descending order based on their expected significances according to expert opinions. Geometric means is applied and general ranking is formed too.

b) Determining relative importance of each criterion: Respondent states the relative importance of criterion $\mathrm{j}$ with respect to previous criterion ( $\mathrm{j}-1)$ by starting from the second criterion. This process continues for each particular criterion.

c) Determining $k_{j}$ coefficient: $k_{j}$ coefficient is determined by using Eq. (1):

$$
k_{j}=\left\{\begin{array}{cc}
1 & j=1 \\
s_{j}+1 & j>1
\end{array} .\right.
$$

d) Calculating qi variable: qi variable is calculated according to Eq.(2):

$$
q_{j}=\left\{\begin{array}{cc}
1 & j=1 \\
\frac{k_{j-1}}{k_{j}} & j>1
\end{array} .\right.
$$

e) Determining importance level of criteria: Relative weights of criteria are determined according to Eq. (3):

$$
w_{j}=\frac{q_{j}}{\sum_{k=1}^{n} q_{k}},
$$

where $w_{j}$ represents the relative weight of criterion $j$.

\section{Findings}

In this study, multi-criteria decision-making methods were used to evaluate the factors to be used in the service quality criteria in three-star hotels in Erzurum. First, the service quality criteria factors in hotel enterprises were determined using expert opinions and literature review. The determined criteria were then weighted since they were not of equal importance.

The SWARA method was then used to list the service quality criteria factors in three-star hotels. The following table was created based on the views of academicians and hotel managers 
in addition to the studies done by Parasuraman et al.; (1985), Gilmore; (2003), Sulek and Hensley; (2004), Murat and Çelik (2007), Kılıç and Bekar; (2012) and Korucuk et al.; (2019).

Table 2. Decision Criteria

\begin{tabular}{lc}
\hline Criteria & Mark \\
\hline Quality of Housekeeping & $\mathrm{C}_{1}$ \\
Quality of Restaurant Services & $\mathrm{C}_{2}$ \\
Quality of Front Office Service & $\mathrm{C}_{3}$ \\
Cleanliness & $\mathrm{C}_{4}$ \\
Flexibility of Service and Transaction & $\mathrm{C}_{5}$ \\
Reliability & $\mathrm{C}_{6}$ \\
Price Compliance & $\mathrm{C}_{7}$ \\
Degree of Courtesy and Respect & $\mathrm{C}_{8}$ \\
\hline
\end{tabular}

A total of 5 questionnaires were presented to academicians (2) and hotel managers (3) who are the stakeholders considered for their expert opinions. Firstly decision matrix is constructed and shown as Table 3 .

Table 3. Decision Matrix of Decision Makers Based on Criteria

\begin{tabular}{ccccccc}
\hline Criteria & DM $_{1}$ & DM $_{2}$ & DM $_{3}$ & DM $_{4}$ & DM $_{5}$ & Geometric Mean \\
\hline $\mathbf{C}_{1}$ & 7 & 7 & 8 & 4 & 5 & 6.001 \\
$\mathrm{C}_{2}$ & 6 & 5 & 3 & 4 & 3 & 4.043 \\
$\mathrm{C}_{3}$ & 4 & 7 & 8 & 2 & 6 & 4.852 \\
$\mathrm{C}_{4}$ & 5 & 4 & 4 & 6 & 3 & 4.282 \\
$\mathrm{C}_{5}$ & 6 & 5 & 5 & 3 & 2 & 3.898 \\
$\mathrm{C}_{6}$ & 5 & 5 & 3 & 2 & 4 & 3.594 \\
$\mathrm{C}_{7}$ & 4 & 3 & 3 & 3 & 2 & 2.930 \\
$\mathrm{C}_{8}$ & 5 & 3 & 3 & 2 & 4 & 3.245 \\
\hline
\end{tabular}

Then $\mathrm{k}_{\mathrm{j}}$ coefficient is calculated and formed as below in terms of two decision makers.

Table 4. Calculation of $\mathrm{k}_{\mathrm{j}}$ coefficient according to two decision makers

Decision Maker $1 \quad$ Decision Maker 2

\begin{tabular}{ccccc}
\hline General & $\mathbf{S}_{\mathbf{j}}$ & $\mathbf{k}_{\mathbf{j}}$ & $\mathbf{S j}_{\mathbf{j}}$ & $\mathbf{k}_{\mathbf{j}}$ \\
$\mathbf{C}_{7}$ & - & - & - & - \\
$\mathbf{C}_{8}$ & 0.10 & 1.10 & 0.15 & 1.15 \\
$\mathbf{C}_{6}$ & 0.15 & 1.15 & 0.20 & 1.20 \\
$\mathbf{C}_{5}$ & 0.10 & 1.10 & 0.15 & 1.15 \\
$\mathbf{C}_{2}$ & 0.10 & 1.10 & 0.15 & 1.15 \\
$\mathbf{C}_{4}$ & 0.15 & 1.15 & 0.20 & 1.20 \\
$\mathbf{C}_{3}$ & 0.20 & 1.20 & 0.05 & 1.05 \\
$\mathbf{C}_{1}$ & 0.10 & 1.10 & 0.15 & 1.15 \\
\hline
\end{tabular}


Following to that $\mathrm{q}_{\mathrm{j}}$ variable is computed and seen as Table $\mathbf{5}$ in terms of two decision makers.

Table 5. Calculation of $\mathrm{q}_{\mathrm{j}}$ variable according to two decision makers

\begin{tabular}{ccccccc}
\hline & \multicolumn{3}{c}{ Decision Maker $\mathbf{1}$} & \multicolumn{3}{c}{ Decision Maker 2 } \\
\hline General ranking & $\mathbf{S}_{\mathbf{j}}$ & $\mathbf{k}_{\mathbf{j}}$ & $\mathbf{q}_{\mathbf{j}}$ & $\mathbf{S}_{\mathbf{j}}$ & $\mathbf{k}_{\mathbf{j}}$ & $\mathbf{q}_{\mathbf{j}}$ \\
$\mathbf{C}_{7}$ & - & - & 1.00 & - & - & 1.00 \\
$\mathbf{C}_{8}$ & 0.10 & 1.10 & 0.909 & 0.15 & 1.15 & 0.870 \\
$\mathbf{C}_{6}$ & 0.15 & 1.15 & 0.790 & 0.20 & 1.20 & 0.725 \\
$\mathbf{C}_{5}$ & 0.10 & 1.10 & 0.718 & 0.15 & 1.15 & 0.630 \\
$\mathbf{C}_{2}$ & 0.10 & 1.10 & 0.653 & 0.15 & 1.15 & 0.548 \\
$\mathbf{C}_{4}$ & 0.15 & 1.15 & 0.568 & 0.20 & 1.20 & 0.457 \\
$\mathbf{C}_{3}$ & 0.20 & 1.20 & 0.473 & 0.05 & 1.05 & 0.435 \\
$\mathbf{C}_{1}$ & 0.10 & 1.10 & 0.430 & 0.15 & 1.15 & 0.378 \\
\hline
\end{tabular}

Finaly $\mathrm{w}_{\mathrm{j}}$ values are computed and criteria are ranked as in Table 6.

Table 6. wj values and ranking of criteria

\begin{tabular}{ccccc}
\hline Criteria & Aritmetic & Geometric & wj values & Ranking \\
$\mathbf{C}_{1}$ & 0.078 & 0.078 & 0.078 & 8 \\
$\mathbf{C}_{2}$ & 0.115 & 0.115 & 0.115 & 5 \\
$\mathbf{C}_{3}$ & 0.088 & 0.088 & 0.088 & 7 \\
$\mathbf{C}_{4}$ & 0.101 & 0.101 & 0.101 & 6 \\
$\mathbf{C}_{5}$ & 0.132 & 0.132 & 0.132 & 4 \\
$\mathbf{C}_{6}$ & 0.144 & 0.144 & 0.144 & 3 \\
$\mathbf{C}_{7}$ & 0.180 & 0.180 & 0.180 & 1 \\
$\mathbf{C}_{8}$ & 0.162 & 0.162 & 0.162 & 2 \\
\hline
\end{tabular}

According to the Table 6, "Price Availability" was found as the most important service quality criteria in three-star hotels. This was followed by "Courtesy and Respect Level", "Reliability", "Service and Process Flexibility", "Restaurant Service Quality" and "Cleanliness" respectively. The criteria considered as the least important include "Quality of Housekeeping" and "Front Office Service Quality".

\section{Conclusion and Recommendations}

In the present environment, service quality has come to hold an important role in businesses when it comes to ensuring customer satisfaction and affording the business the highly needed competitive advantage. To this end, the determination of the criteria affecting the service quality and establishing the ranking of the said criteria have become significant considerations for any business. Innovations and standards in service quality are expected to reduce operating costs in the long run, as well as support profitability rates and a sustainable business presence.

This study administered a survey on managers of three-star hotels in Erzurum, some managers working in the tourism sector, and academicians. The result of the survey led to the ranking of service quality criteria based on the levels of importance of the criteria. The ranking, in order of importance, of the service quality criteria considered was "Price Availability", 
"Courtesy and Respect Level", "Reliability" "Service and Process Flexibility", "Quality of Restaurant Services" and "Cleanliness". "Quality of Housekeeping" and "Front Office Service Quality", respectively were found to be the least important main criteria for service quality. In this study, experts who were thought to be stakeholders in the subject area were interviewed. However, due to time constraints, the research only considered Erzurum Province. Future studies may choose to expand the area of coverage to include and compare the results in more provinces. Similarly, research may also be considered in different fields other than that considered in this study. Furthermore, other multi-criteria decision-making methods and/or other parametric or non-parametric methods could be applied in future studies. Adding fuzzy logic and comparing the results could also be considered as a way of improving future studies

\section{References}

Aghdaie, M. H., Zolfani, S. H., \& Zavadskas, E. K. (2013). Decision making in machine tool selection: An integrated approach with SWARA and COPRAS-G methods. Economics of Engineering Decisions, 24(1), 5-17.

Akyurt, H. (2021). Entropi yöntemi ile hizmet kalitesinin ölçülmesi: Ordu ili dört ve beş yıldızlı otelleri üzerine araştırma. Journal of Social and Humanities Sciences Research, 8(66), 451462.

Alimardani, M., Zolfani, S. H., Aghdaie, M. H., \& Tamosaitiene, J. (2013). A novel hybrid SWARA and VIKOR methodology for supplier selection in an agile environment. Technological and Economic Development of Economy, 19(3), 533-548.

Ashraf, S., Ilyas, R., Imtiaz, M., \& Ahmad, S. (2018). Impact of service quality, corporate image and perceived value on brand loyalty with presence and absence of customer satisfaction: A study of four service sectors of Pakistan. International Journal of Academic Research in Business and Social Science, 8(2), 452-474.

Attallah, F. N. (2015). Evaluation Of Perceived Service Quality Provided By Tourism Establishments in Egypt. Tourism And Hospitality Research, 1-12.

Çabuk, S., Nakıboğlu, B., \& Canoğlu, M. (2013). Algılanan Otel İmajı ve Hizmet Kalitesi ile Tekrar Satın Alma Niyeti Arasındaki İlişkiler. Anatolia: Turizm Araştırmaları Dergisi, 24 (1), 96-108.

Dahooie, J. H., Abadi, E. B. J., Vanaki, A. S., \& Firoozfar, H. R. (2018). Competency-based IT personnel selection using a hybrid SWARA and ARAS-G methodology. Human Factors and Ergonomics in Manufacturing \& Service Industries, 28(1), 5-16.

Demirağ, B., \& Durmaz, Y. (2019). Algılanan Hizmet Kalitesinin Algılanan Değer ve Tutumsal Marka Sadakati Üzerindeki Etkisinin İncelenmesi: 5 Yıldızlı Sayfiye ve Şehir Otelleri Örneği. OPUS Uluslararası Toplum Araştırmaları Dergisi, 11(18), 693-726.

Erdal, H., \& Korucuk, S. (2016). Toplam Kalite Yönetimine Askeri Bakış Açısi: Toplam Kalite Liderliği, Karabük Ünivesitesi, Sosyal Bilimler Enstitüsü Dergisi, 6(2), 465-484.

Gilmore, A. (2003). Services, Marketing and Management. (1st Edition), United States: Sage Publications Inc.

Ghenai, C., Albawab, M., \& Bettayeb, M. (2020). Sustainability indicators for renewable energy systems using multi-criteria decision-making model and extended SWARA/ARAS hybrid method. Renewable Energy, 146, 580-597. 
Günaydın, Y. (2015). Hizmet kalitesinin müşteri sadakatine etkisi: Aegean Dream Hotel örneği. International Journal of Social Sciences and Education Research, 1(1), 16-34.

Han, S. L., \& Baek, S. (2004). Antecedents and Consequences of Service Quality in Online Banking: An Application of The Servqual Instrument. Advances in Consumer Research, 31 (1), 208-214.

Hsieh, L-F., Lin, L-H., \& Lin, Y-Y. (2008). A service quality measurement architecture for hot spring hotels in Taiwan. Tourism Management, 29, 429-438.

Jasinskas, E., Streimikiene, D., Svagzdiene, B., \& Simanavicius, A. (2016). Impact of hotel service quality on the loyalty of customers. Economic Research-Ekonomska Istraživanja, 29(1), 559572.

Kahraman, N. (1996). Toplam Kalite Yönetiminin Turizm Sektöründe Önemi. Hacettepe Üniversitesi İktisadi ve İdari Bilimler Fakültesi Dergisi, 14(2), 179-184.

Kenzhebayeva, A. (2012). Turizm Sektöründe Hizmet Kalitesi: Türkiye ve Kazakistan'daki Termal Otel İşletmelerinde Karşılaştırmalı Bir Araştırma. Unpublished Master Thesis, Gazi Üniversitesi, Eğitim Bilimleri Enstitüsü, Ankara.

Kılıcı, L., Özdağoğlu, A., \& Güler, M. E. (2020). Çok Kriterli Karar Verme Yöntemleri ile Termal Turizmde Hizmet Kalitesi Boyutlarının ve Otel Alternatiflerinin Önceliklendirilmesi. Journal of Yaşar University, 15(57), 143-159.

K1lıç, B., \& Eleren, D. (2010). Termal Otel İşletmelerinde Hizmet Kalitesinin Ölçülmesi. Süleyman Demirel Üniversitesi İktisadi ve İdari Bilimler Fakültesi Dergisi, 15(3), 119-142.

Kılıç, B., \& Bekar, A. (2012). Üniversite kampüsü içerisinde yiyecek içecek hizmeti sunan işletmelerin hizmet kalitesinin değerlendirilmesi ve hizmet kalitesinin müşteri memnuniyetine etkisi. Seyahat ve Otel İşletmeciliği Dergisi, 9(3), 38-51.

Korucuk, S. (2018). İmalat İşletmelerinde Lojistik Hizmet Kalitesinin İşletme Verimliliğine Etkisinin Lojistik Regresyon Analizi İle Belirlenmesi: Erzincan İli Örneği. Erzincan Üniversitesi Sosyal Bilimler Enstitüsü Dergisi, 11(2), 30-43.

Korucuk, S. (2021). Ordu Ve Giresun İllerinde Kentsel Lojistik Performans Unsurlarına Yönelik Karşılaştırmalı Bir Analiz. Dicle Üniversitesi Sosyal Bilimler Enstitüsü Dergisi, 13(26), 141155.

Korucuk, S., Kurnuç, M., \& Küçük, O. (2015). Kalite Güvence Sistemi Uygulamalarının İş Süreçleri Ve Örgütsel Performans İlişkisinin Ölçülmesi: Bir Uygulama. The International New Issues in SOcial Sciences, 1, 71- 90.

Korucuk, S., Akyurt, H., \& Turpcu, E. (2019). Otel İşletmelerinde Hizmet Kalitesinin Entropi Yöntemi ile Ölçülmesi: Giresun İlindeki Üç Yıldızlı Oteller Üzerine Bir Araştırma. Manas Sosyal Araştırmalar Dergisi, 8(1), 697-709.

Kotler, P., Bowen, J. T., \& Makens, J. C. (2003). Marketing Del Turismo. Pearson, Prentice Hall.

Kouchaksarae1, R. H., Zolfanı, S. H., \& Golabch1, M. (2015). Glasshouse Locating Based On SWARA-COPRAS Approach. International Journal of Strategic Property Management, 19(2), 111-122.

Kurtz, D. L., \& Clow, K. E. (1998). Services marketing. United States: John Wiley \& Sons. 
Murat, G., \& Çelik, N. (2007). Analitik Hiyerarşi Süreci Yöntemi İle Otel İşletmelerinde Hizmet Kalitesini Değerlendirme: Bartın Örneği. Uluslararası Yönetim İktisat ve İsletme Dergisi, 3 (6), 1-20.

Nadiri, H., \& Hussain, K. (2005). Perceptions of Service Quality in North Cyprus Hotels. International Journal of Contemporary Hospitality Management, 17(6), 469-480.

Nguyen, P. H. (2021). A Fuzzy Analytic Hierarchy Process (FAHP) Based on SERVQUAL for Hotel Service Quality Management: Evidence From Vietnam. The Journal Of Asian Finance, Economics, And Business, 8(2), 1101-1109.

Onurlubaş, E., \& Öztürk, D. (2020). Hizmet Kalitesinin Müşteri Memnuniyeti Üzerindeki Etkisi: Butik Oteller Üzerine Bir Uygulama. Gümüşhane Üniversitesi Sosyal Bilimler Enstitüsü Elektronik Dergisi, 11(3), 756-766.

Parasuraman, A., Zeithaml, V. A., \& Berry, L. L. (1985). A Conceptual Model of Service Quality and its Implications for Future Research. Journal of Marketing, 49, 41-50.

Prajapati, H., Kant, R., \& Shankar, R. (2019). Prioritizing the solutions of reverse logistics implementation to mitigate its barriers: A hybrid modified SWARA and WASPAS approach. Journal of Cleaner Production, 240, 118219.

Rani, P., Mishra, A. R., Krishankumar, R., Mardani, A., Cavallaro, F., Soundarapandian Ravichandran, K., \& Balasubramanian, K. (2020). Hesitant Fuzzy SWARA-Complex Proportional Assessment Approach for Sustainable Supplier Selection (HF-SWARACOPRAS). Symmetry, 12(7), 1152.

Roy, J., Kumar Sharma, H., Kar, S., Kazimieras Zavadskas, E., \& Saparauskas, J. (2019). An Extended Copras Model For Multi-Criteria Decision-Making Problems and Its Application in Web-Based Hotel Evaluation and Selection. Economic research-Ekonomska istraživanja, 32(1), 219-253.

Ruzgys, A., Volvačiovas, R., Ignatavičius, Č., \& Turskis, Z. (2014). Integrated Evaluation of External Wall Insulation in Residential Buildings Using SWARA-TODIM MCDM method. Journal of Civil Engineering and Management, 20(1), 103-110.

Stanujkic, D., Karabasevic, D., \& Zavadskas, E. K. (2015). A Framework For The Selection of A Packaging Design Based on The SWARA Method. Inzinerine Ekonomika-Engineering Economics, 26(2), 181-187.

Sulek, J. M., \& Hensely, R. L. (2004). The relative importance of food, atmosphere, and fairness of wait: The case of a full-service restaurant. Cornell Hotel and Restaurant Administration Quarterly, 45(3), 235-247.

Temizel, G., \& Garda, B. (2017). Konaklama İşletmelerinde Hizmet Kalitesi Kavramı ve Hizmet Kalitesinin Ölçülmesinde Kullanılan Modeller. Selçuk Universitesi Journal of Social and Technical Researches, 14, 161-171.

Tian-Cole, S., \& Cromption, J. L. (2003). A conceptualization of the relationshipsbetween service quality and visitor satisfaction, and their links to destinationselection. Leisure Studies, 22, 65-80.

Tsang, N., \& Ou, H. (2000). Service Quality in China's Hotel Industry: A Perspective from Tourists and Hotel Managers. International Journal of Contemporary Hospitality Management, 12(5), 316-326. 
Tsaur, S-H., \& Lin, Y-C. (2004). Promoting Service Quality in Tourist Hotels: The Role of HRM practices and Service Behavior. Tourism Management, 25, 471-481.

Ulutaş, A., Karakuş, C. B., \& Topal, A. (2020). Location selection for logistics center with fuzzy SWARA and CoCoSo methods. Journal of Intelligent \& Fuzzy Systems, 38(4), 4693-4709.

Urosevic, S., Karabasevic, D., Stanujkic, D., \& Maksimovic, M. (2017). An Approach to Personnel Selection in the Tourism Industry Based on the SWARA and the WASPAS Methods. Economic Computation and Economic Cybernetics Studies and Research, 51(1), 7588.

Vesković, S., Stević, Ž., Stojić, G., Vasiljević, M., \& Milinković, S. (2018). Evaluation of the railway management model by using a new integrated model DELPHI-SWARAMABAC. Decision Making: Applications in Management and Engineering, 1(2), 34-50.

Zolfani, S.H., \& Bahrami, M. (2014). Investment prioritizing in high tech industries based on SWARA-COPRAS approach. Technological and Economic Development of Economy, 20(3), 534-553.

(C) 2021 by the authors. Submitted for possible open access publication under the terms and (c) (i) conditions of the Creative Commons Attribution (CC BY) license (http://creativecommons.org/licenses/by/4.0/). 